\title{
Exploitation of mitochondrial nad6 as a complementary marker for studying population variability in Lepidoptera
}

Karina L. Silva-Brandão ${ }^{1}$, Mariana L. Lyra ${ }^{2}$, Thiago V. Santos ${ }^{1}$, Noemy Seraphim ${ }^{3}$, Karina C. Albernaz ${ }^{1}$, Vitor A.C. Pavinato ${ }^{1}$, Samuel Martinelli ${ }^{4}$, Fernando L. Cônsoli ${ }^{1}$ and Celso Omoto ${ }^{1}$

${ }^{1}$ Departamento de Entomologia e Acarologia, Escola Superior de Agricultura "Luiz de Queiroz", Universidade de São Paulo, Piracicaba, SP, Brazil.

${ }^{2}$ Departamento de Zoologia, Instituto de Biociências, Universidade Estadual Paulista "Júlio de Mesquita Filho", Rio Claro, SP, Brazil.

${ }^{3}$ Programa de Pós-Graduação em Ecologia, Departamento de Biologia Animal,

Universidade Estadual de Campinas, Campinas, SP, Brazil.

${ }^{4}$ Monsanto do Brazil, São Paulo, SP, Brazil.

\begin{abstract}
The applicability of mitochondrial nad6 sequences to studies of DNA and population variability in Lepidoptera was tested in four species of economically important moths and one of wild butterflies. The genetic information so obtained was compared to that of cox 1 sequences for two species of Lepidoptera. nad 6 primers appropriately amplified all the tested DNA targets, the generated data proving to be as informative and suitable in recovering population structures as that of cox1. The proposal is that, to obtain more robust results, this mitochondrial region can be complementarily used with other molecular sequences in studies of low level phylogeny and population genetics in Lepidoptera.
\end{abstract}

Key words: cytochrome c oxidase I, Diatraea saccharalis, DNA polymorphism, Hermeuptychia atalanta, Noctuidae.

Received: April 4, 2011; Accepted: July 31, 2011.

Lepidoptera is the best-known order among insects, with relatively well-established systematic for most groups (Freitas et al., 2006). It presents a number of monophagous and polyphagous moth species, capable of inflicting severe losses in several of the major agricultural commodities worldwide (Barros et al., 2010; Molina-Ochoa et al., 2010). On the other hand, a rising number of butterfly species have been targeted in conservation programs, leading these insects to be considered flagship taxa for conservation (New, 1997). Knowledge on species genetic relationships, population structures and patterns of gene flow among populations is a key, not only to the development of pest-management programs (Krafsur, 2005), but also to the selection and use of organisms for conservation initiatives (Dale and Beyeler, 2001).

The usefulness of animal mitochondrial DNA (mtDNA), as a molecular marker for studies of population structure, is well-known on account of ease in manipulation, rapid mutation rate, supposed lack of significant recombination, and availability of universal primers (Avise,

Send correspondence to Karina Lucas Silva-Brandão. Departamento de Entomologia e Acarologia, Escola Superior de Agricultura "Luiz de Queiroz", Universidade de São Paulo, Av. Pádua Dias 11, 13418-900 Piracicaba, SP, Brazil. E-mail: klsilva@ gmail.com.
1986; Moritz et al., 1987; Simon et al., 1994). Recently, the use of the cytochrome c oxidase I gene ( $\operatorname{cox} 1$ ) has largely replaced that of other mitochondrial regions in studies with animals, including many Lepidoptera (Silva-Brandão et al., 2009), ever since its proposal as a "DNA barcode" for species diagnosis and delimitation (Hebert et al., 2004), as well as its historical application in population genetics and phylogeographic studies (Avise, 2000). Notwithstanding, the recent availability of complete mitochondrial genomes of several Lepidoptera species (Cameron and Whiting, 2008; Yang et al., 2009), has facilitated the evaluation and establishment of new genes for studying population genetics within the group. Subunits of nicotinamide adenine dinucleotide dehydrogenase (NADH), such as nad1 (Miller et al., 2009), nad4 (Gomez et al., 2009) and nad5 (Meraner et al., 2008), are beginning to be exploited in studies of population structure. These genes have already been widely used in studies at higher taxonomic levels (Weller et al., 1994; Morinaka et al., 1999; Yagi et al., 1999), subunits of nad having proved to be more variable than the other mitochondrial regions frequently used in such instances (Cameron and Whiting, 2008).

The subunits of both cox and nad are related to the oxidative phosphorylation complexes encoded by the mito- 
chondrial genome (Montooth et al., 2009). The gene that codifies subunit 6 of NADH (nad6) provides instructions for making a protein, NADH dehydrogenase 6 , officially named "mitochondrially encoded NADH dehydrogenase 6", which is part of a large enzymatic machinery known as Complex I (Genetics Home Reference, 2011). The nad6 gene ranges from 480 to $540 \mathrm{bp}$ within the mitochondrial genomes of the 32 species of Lepidoptera available in GenBank.

Both the applicability of primers designed to amplify the mitochondrial gene nad6, and the efficacy of this region in differentiating populations, were tested with four species of moths considered economically important in Brazil, as well as one wild butterfly species. The genetic information so obtained was also compared with information provided by coxl on two of these species, the sugarcane borer Diatraea saccharalis (F.), the main pest of sugarcane (Saccharum officinarum L.) and an important one of corn (Zea mays L.), as well as Hermeuptychia atalanta Butler, a widely distributed Nymphalidae butterfly.

A total of 107 specimens from five species of Lepidoptera were sampled from distinct populations (Table 1). Total genomic DNA was obtained from the thoracic tissues of each, according to the Invisorb Spin Tissue kit (Uniscience) protocol. Extracted DNA was stored in a TE buffer at $-20^{\circ} \mathrm{C}$. Primers for nad6 gene amplification were designed, based on the alignment of complete mitochondrial genomes of all the Lepidoptera species available in GenBank (alignment available upon request). Forward and reverse primers were named according to their reference positions on the mitochondrial genome of Manduca sexta (L.) (GenBank accession number NC_010266), the forward primer thus beginning at 10090 (tPro-J100905ATCWATAATCTCCAAAATTAT 3), and the reverse at 10624 (ND6-N10624-5 GGNCCATAAAAAATATTWGT 3), thereby totaling $534 \mathrm{bp}$. Complete (for D. saccharalis) or partial (for H. atalanta) coxl fragments were amplified according to Silva-Brandão et al. (2008).

The nad 6 gene was amplified using $1 \mu \mathrm{L}$ of total DNA, $2.0 \mathrm{mM}$ of $\mathrm{MgCl}_{2}, 40 \mu \mathrm{M}$ of dNTPs, $0.2 \mathrm{mM}$ of each primer, 1U of GoTaq DNA Polymerase (Promega), and $10 \%$ of 10X Taq buffer, in $25 \mu \mathrm{L}$ of final volume. The amplification protocol was as follows: an initial denaturation step at $94{ }^{\circ} \mathrm{C}$ for $5 \mathrm{~min}, 35$ cycles of denaturation at $94{ }^{\circ} \mathrm{C}$ for $45 \mathrm{~s}$, annealing at $45^{\circ} \mathrm{C}$ for $45 \mathrm{~s}$, and elongation at $60^{\circ} \mathrm{C}$ for $1.5 \mathrm{~min}$, followed by an extension step at $60^{\circ} \mathrm{C}$ for $5 \mathrm{~min}$. Aliquots were then analyzed by electrophoresis in $1 \%$ agarose gel. After purifying from primers and deoxynucleotides with ExoSAP-IT (GE Healthcare), the PCR products were then sequenced by an ABI Prism BigDye Kit protocol in an ABI 3700 automated sequencer (Applied Biosystems), with the forward primer used for amplification. Sequences were analyzed with the FinchTV 1.4.0 program (Geospiza Inc.), and manually aligned with BioEdit 7.0.5.3 (Hall, 1999).
Sequence divergence was quantified with the $p$-distance model of nucleotide substitution (Nei and Kumar, 2000), implemented into the MEGA v.5.0 program (Tamura et al., 2011). Employing the same model and program, the Neighbor-Joining (NJ) clustering algorithm (Saitou and Nei, 1987) was applied for graphically obtaining phenetic distances among $D$. saccharalis and $H$. atalanta individuals. Robustness of each branch was defined with the non-parametric bootstrapping procedure (Felsenstein, 1985), with 1,000 replicates. Standard parameters of DNA polymorphism were estimated in DnaSP v.5.10 (Librado and Rozas, 2009) and MEGA v.5.0 (Tamura et al., 2011).

The primers proposed here adequately served for amplifying the nad6 region in all the species tested (GenBank accession numbers are shown in Table 2). The reported sequence length variation was due to the quality of the last bases sequenced. DNA polymorphism was low throughout (Table 2), although low genetic variability is the general rule for lepidopteran pest species (Coates et al., 2004; Saw et al., 2006; Behere et al., 2007). Genetic distances for Alabama argillacea (Hübner) and Heliothis virescens (F.) populations ranged from 0.0 to 0.006 , and from 0.0 to 0.032 for Spodoptera frugiperda (J.E. Smith). DNA polymorphism and pairwise genetic distances were higher in S. frugiperda populations than in all the other species, with most nucleotide substitutions being non-synonymous (Table 2). Worthy of note, these populations were sampled on two different crops (corn and cotton), even though no difference was found between populations collected in these two host plants in a previous study that applied RAPD markers (Martinelli et al., 2006). Nonetheless, corn and rice biotypes of S. frugiperda have already been recorded in Brazil, when using AFLP markers (Busato et al., 2004).

As regards $D$. saccharalis populations, the analysis of information provided by nad6 and coxl showed the same amount of DNA variation for the two (Table 2). Genetic distances based on the two regions ranged from 0.0 to 0.004 . However, the general pattern of genetic divergence was different, for with the overall increase, coxl divergence becoming more pronounced at the $3^{\text {rd }}$ codon position (Figure $1 \mathrm{~A}$ and $\mathrm{B}$ ). Both regions presented similar results in recovering population structure (Figure S1). Pairwise genetic distances of concatenated data also ranged from 0.0 to $0.004, \mathrm{NJ}$ analysis resulting in a topology similar to that based only on cox 1 sequences (Figure $2 \mathrm{~A}$ ).

The 5' end of coxl (the proposed "barcode") and nad6 yielded almost the same results for $H$. atalanta, with similar values for general parameters of DNA polymorphism (Table 2). Pairwise genetic distances among nad6 sequences ranged from 0.0 to 0.007 , and among cox 1 from 0.0 to 0.006 . Divergences, which occurred mainly at the $3^{\text {rd }}$ codon position (Table 2 ), became progressively greater together with the overall increase (Figure $1 \mathrm{C}$ and $\mathrm{D}$ ). Phenetic relationships obtained with the two datasets were different, although both regions recovered a cluster com- 
Table 1 - Species of Lepidoptera, populations and number of specimens used to test the primers designed to amplify the mitochondrial region nad6.

\begin{tabular}{|c|c|c|c|c|}
\hline Species (Family) & Host plant & Populations: Locality, State (Code*; number of specimens) & Latitude & Longitude \\
\hline Alabama argillacea & Cotton & Campina Grande, PB (2) & $7^{\circ} 13^{\prime} 52^{\prime} \mathrm{S}$ & $35^{\circ} 52^{\prime \prime} 55.1 ” \mathrm{~W}$ \\
\hline \multirow[t]{8}{*}{ (Noctuidae) } & & Campo Verde, MT (2) & $15^{\circ} 32^{\prime} 42.7^{\prime} \mathrm{S}$ & $55^{\circ} 9 " 55.6 ” \mathrm{~W}$ \\
\hline & & Chapadão do Sul, MS (3) & $18^{\circ} 46^{\prime} 44^{\prime \prime} \mathrm{S}$ & $52^{\circ} 36 " 59.4 ” \mathrm{~W}$ \\
\hline & & Cristalina, GO (2) & $16^{\circ} 46^{\prime} 0.9^{\prime \prime} \mathrm{S}$ & $47^{\circ} 36^{\prime} 29.9 ’ \mathrm{~W}$ \\
\hline & & Luis Eduardo Magalhães, BA (2) & $12^{\circ} 51^{\prime} 57.9 ” \mathrm{~S}$ & $45^{\circ} 47^{\prime} 53.7^{\prime \prime} \mathrm{W}$ \\
\hline & & Montividiu, GO (2) & $17^{\circ} 47^{\prime} 49.1^{\prime \prime} \mathrm{S}$ & $50^{\circ} 54^{\prime} 0.2^{\prime \prime} \mathrm{W}$ \\
\hline & & Primavera do Leste, MT (1) & $15^{\circ} 33^{\prime} 32.7^{\prime \prime} \mathrm{S}$ & $54^{\circ} 17^{\prime} 51.2^{\prime \prime} \mathrm{W}$ \\
\hline & & Roda Velha, BA (2) & $12^{\circ} 41^{\prime} 48.6 ” \mathrm{~S}$ & $45^{\circ} 49^{\prime} 57.6 ” \mathrm{~W}$ \\
\hline & & São Disidério, BA (2) & $12^{\circ} 21^{\prime} 7.6 ” \mathrm{~s}$ & $44^{\circ} 59^{\prime} 3.2^{\prime \prime} \mathrm{W}$ \\
\hline Diatraea saccharalis & Corn & Bambuí, MG (Ds_MG_Zm; 3) & $20^{\circ} 1{ }^{\prime} 8.7^{\prime \prime} \mathrm{S}$ & $45^{\circ} 57^{\prime} 37.8^{\prime \prime} \mathrm{W}$ \\
\hline \multirow[t]{9}{*}{ (Crambidae) } & & Catalão, GO (Ds_GO_Zm; 3) & $18^{\circ} 9^{\prime} 43.6^{\prime \prime} \mathrm{S}$ & $47^{\circ} 56^{\prime} 38.2^{\prime \prime} \mathrm{W}$ \\
\hline & & Itaberá, SP (Ds_SP_Zm; 3) & $23^{\circ} 51^{\prime} 20.7 ” \mathrm{~S}$ & $49^{\circ} 8^{\prime} 8.7^{\prime \prime} \mathrm{W}$ \\
\hline & & Passo Fundo, RS (Ds_RS_Zm; 3) & $28^{\circ} 15^{\prime} 38.5^{\prime} \mathrm{S}$ & $52^{\circ} 24^{\prime} 28.8^{\prime \prime} \mathrm{W}$ \\
\hline & & Ponta Grossa, PR (Ds_PR_Zm; 3) & $25^{\circ} 5^{\prime} 40.4 ” \mathrm{~S}$ & $50^{\circ} 9^{\prime} 47.9^{\prime} \mathrm{W}$ \\
\hline & & Primavera do Leste, MT (Ds_MT_Zm; 3) & $15^{\circ} 33^{\prime} 32.7^{\prime \prime} \mathrm{S}$ & $54^{\circ} 17^{\prime} 51.2^{\prime \prime} \mathrm{W}$ \\
\hline & Sugarcane & Jaboticabal, SP (Ds_SP1_So; 3) & $21^{\circ} 15^{\prime} 21.7^{\prime \prime} \mathrm{S}$ & $48^{\circ} 19^{\prime} 22^{\prime \prime} \mathrm{W}$ \\
\hline & & Maringá, PR (Ds_PR_So; 3) & $23^{\circ} 25^{\prime} 34.6^{\prime \prime} \mathrm{S}$ & $51^{\circ} 56^{\prime} 8.8^{\prime \prime} \mathrm{W}$ \\
\hline & & Monte Alegre, MG (Ds_MG_So; 3) & $21^{\circ} 24^{\prime} 4.4 ” \mathrm{~S}$ & $46^{\circ} 15^{\prime} 12.4^{\prime \prime} \mathrm{W}$ \\
\hline & & Pradópolis, SP (Ds_SP2_So; 3) & $21^{\circ} 21^{\prime} 35.3^{\prime \prime} \mathrm{S}$ & $48^{\circ} 4^{\prime} 21.5^{\prime \prime} \mathrm{W}$ \\
\hline Heliothis virescens & Cotton & Chapadão do Sul, MS (3) & $18^{\circ} 46^{\prime} 44^{\prime \prime} \mathrm{S}$ & $52^{\circ} 36 " 59.4 ” \mathrm{~W}$ \\
\hline \multirow[t]{7}{*}{ (Noctuidae) } & & Luis Eduardo Magalhães, BA (3) & $12^{\circ} 51^{\prime} 57.9 ” \mathrm{~S}$ & $45^{\circ} 47^{\prime} 53.7^{\prime \prime} \mathrm{W}$ \\
\hline & & Palmeiras, GO (3) & $16^{\circ} 47^{\prime} 23^{\prime \prime} \mathrm{S}$ & $49^{\circ} 55^{\prime} 58.5^{\prime} \mathrm{W}$ \\
\hline & & Primavera do Leste, MT (3) & $15^{\circ} 33^{\prime} 32.7^{\prime \prime} \mathrm{S}$ & $54^{\circ} 17^{\prime} 51.2^{\prime \prime} \mathrm{W}$ \\
\hline & & Riachão das Neves, BA (3) & $11^{\circ} 44^{\prime} 49^{\prime \prime} \mathrm{S}$ & $44^{\circ} 54^{\prime} 25.5^{\prime \prime} \mathrm{W}$ \\
\hline & & Rio Verde, GO (3) & $16^{\circ} 46^{\prime} 0.9^{\prime \prime} \mathrm{S}$ & $47^{\circ} 36^{\prime} 29.9^{\prime \prime} \mathrm{W}$ \\
\hline & & Sapezal, MT (3) & $12^{\circ} 59^{\prime} 21.8^{\prime \prime} \mathrm{S}$ & $58^{\circ} 45^{\prime} 52^{\prime \prime} \mathrm{W}$ \\
\hline & & Sinop, MT (3) & $11^{\circ} 52^{\prime} 31.3^{\prime \prime} \mathrm{S}$ & $55^{\circ} 30^{\prime} 17.7 ’ \mathrm{~W}$ \\
\hline Hermeuptychia atalanta & - & Campinas, SP (Ha_SP; 3 ) & $22^{\circ} 54^{\prime} 25.4 ” \mathrm{~S}$ & $47^{\circ} 3^{\prime} 47.8^{\prime \prime} \mathrm{W}$ \\
\hline \multirow[t]{6}{*}{ (Nymphalidae) } & & Catuípe, RS (Ha_RS; 3) & $28^{\circ} 14^{\prime} 59.8^{\prime \prime} \mathrm{S}$ & $54^{\circ} 0^{\prime} 20.3^{\prime \prime} \mathrm{W}$ \\
\hline & & Jundiaí, SP (Ha_SP2; 3) & $23^{\circ} 11^{\prime} 15.1 ” \mathrm{~S}$ & $46^{\circ} 53^{\prime} 9.3^{\prime \prime} \mathrm{W}$ \\
\hline & & Paranaíta, MT (Ha_MT; 3) & $9^{\circ} 40^{\prime} 22.7 ” \mathrm{~S}$ & $56^{\circ} 28^{\prime} 50.3^{\prime \prime} \mathrm{W}$ \\
\hline & & Porto Mauá, RS (Ha_RS2; 3) & $27^{\circ} 34^{\prime} 15.7^{\prime} \mathrm{S}$ & $54^{\circ} 40^{\prime} 13.4^{\prime \prime} \mathrm{W}$ \\
\hline & & Santa Teresinha, BA (Ha_BA; 3) & $12^{\circ} 44^{\prime} 59.4 " \mathrm{~S}$ & $39^{\circ} 31^{\prime} 6.1^{\prime \prime} \mathrm{W}$ \\
\hline & & Sousas, SP (Ha_SP3; 3) & $22^{\circ} 52^{\prime} 52^{\prime \prime} \mathrm{S}$ & $46^{\circ} 57^{\prime} 57^{\prime \prime} \mathrm{W}$ \\
\hline Spodoptera frugiperda & Cotton & Acreúna, GO (2) & $17^{\circ} 23^{\prime} 41.7^{\prime \prime} \mathrm{S}$ & $50^{\circ} 22^{\prime} 57^{\prime \prime} \mathrm{W}$ \\
\hline \multirow[t]{9}{*}{ (Noctuidae) } & & Barreiras, BA (2) & $12^{\circ} 8^{\prime} 55.22^{\prime} \mathrm{S}$ & $44^{\circ} 59^{\prime} 45.78^{\prime \prime} \mathrm{W}$ \\
\hline & & Primavera do Leste, MT (2) & $15^{\circ} 33^{\prime} 32.7^{\prime} \mathrm{S}$ & $54^{\circ} 17^{\prime} 51.2^{\prime \prime} \mathrm{W}$ \\
\hline & & Unaí, MG (2) & $16^{\circ} 20^{\prime} 38.11^{\prime \prime} \mathrm{S}$ & $46^{\circ} 54^{\prime} 30.04^{\prime \prime} \mathrm{W}$ \\
\hline & Corn & Douradina, MS (1) & $22^{\circ} 2^{\prime} 12.59^{\prime \prime} \mathrm{S}$ & $54^{\circ} 36^{\prime} 42.07^{\prime \prime} \mathrm{W}$ \\
\hline & & Luis Eduardo Magalhães, BA (1) & $12^{\circ} 51^{\prime} 57.9 ” \mathrm{~S}$ & $45^{\circ} 47^{\prime} 53.7^{\prime \prime} \mathrm{W}$ \\
\hline & & Passo Fundo, RS (1) & $28^{\circ} 15^{\prime} 38.5^{\prime \prime} \mathrm{S}$ & $52^{\circ} 24^{\prime} 28.8^{\prime \prime} \mathrm{W}$ \\
\hline & & Ponta Grossa, PR (2) & $25^{\circ} 5^{\prime} 40.4 ” \mathrm{~S}$ & $50^{\circ} 9^{\prime} 47.9^{\prime \prime} \mathrm{W}$ \\
\hline & & Sapezal, MT (1) & $12^{\circ} 59^{\prime} 21.8^{\prime} \mathrm{S}$ & $58^{\circ} 45^{\prime} 52^{\prime \prime} \mathrm{W}$ \\
\hline & & Uberlândia, MG (2) & $18^{\circ} 54^{\prime} 52.88^{\prime \prime} \mathrm{S}$ & $48^{\circ} 16^{\prime} 8.43^{\prime \prime} \mathrm{W}$ \\
\hline
\end{tabular}

*Code was applied only for populations analyzed with both markers (coxl and nado). 


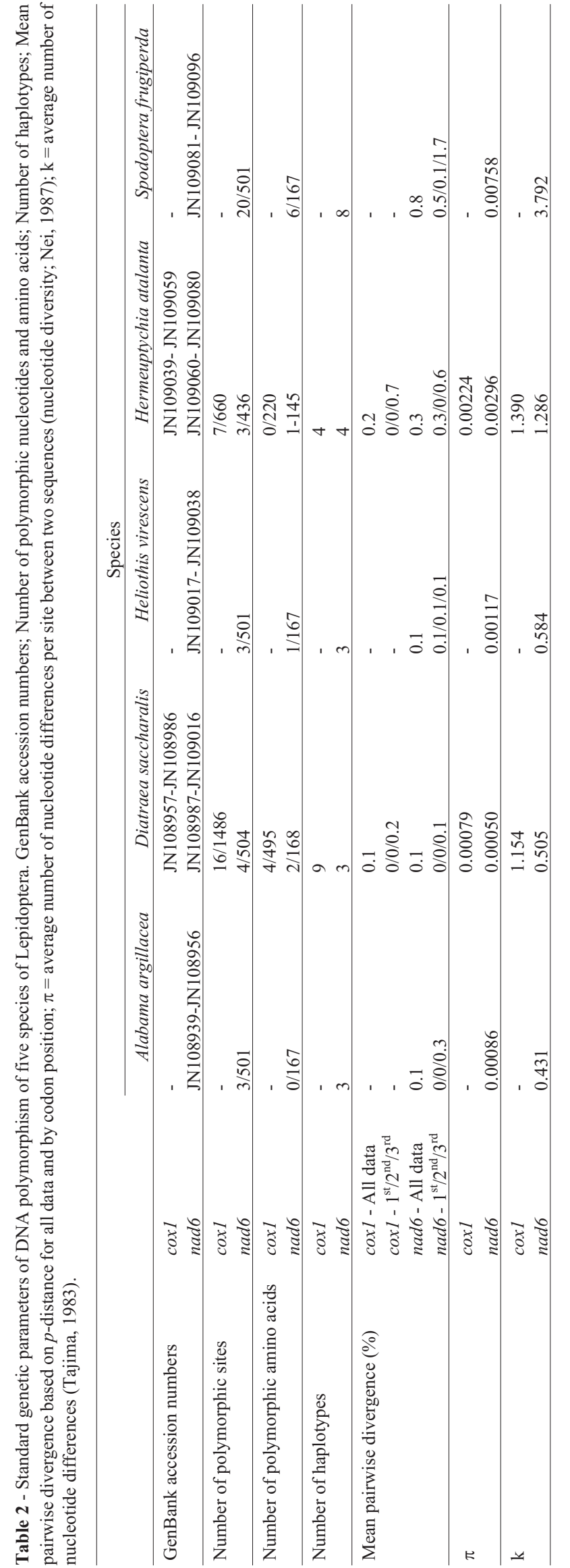

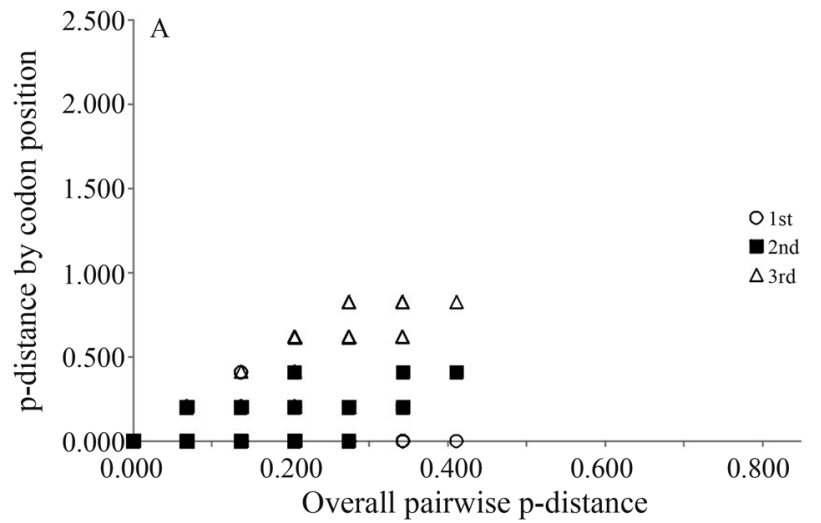
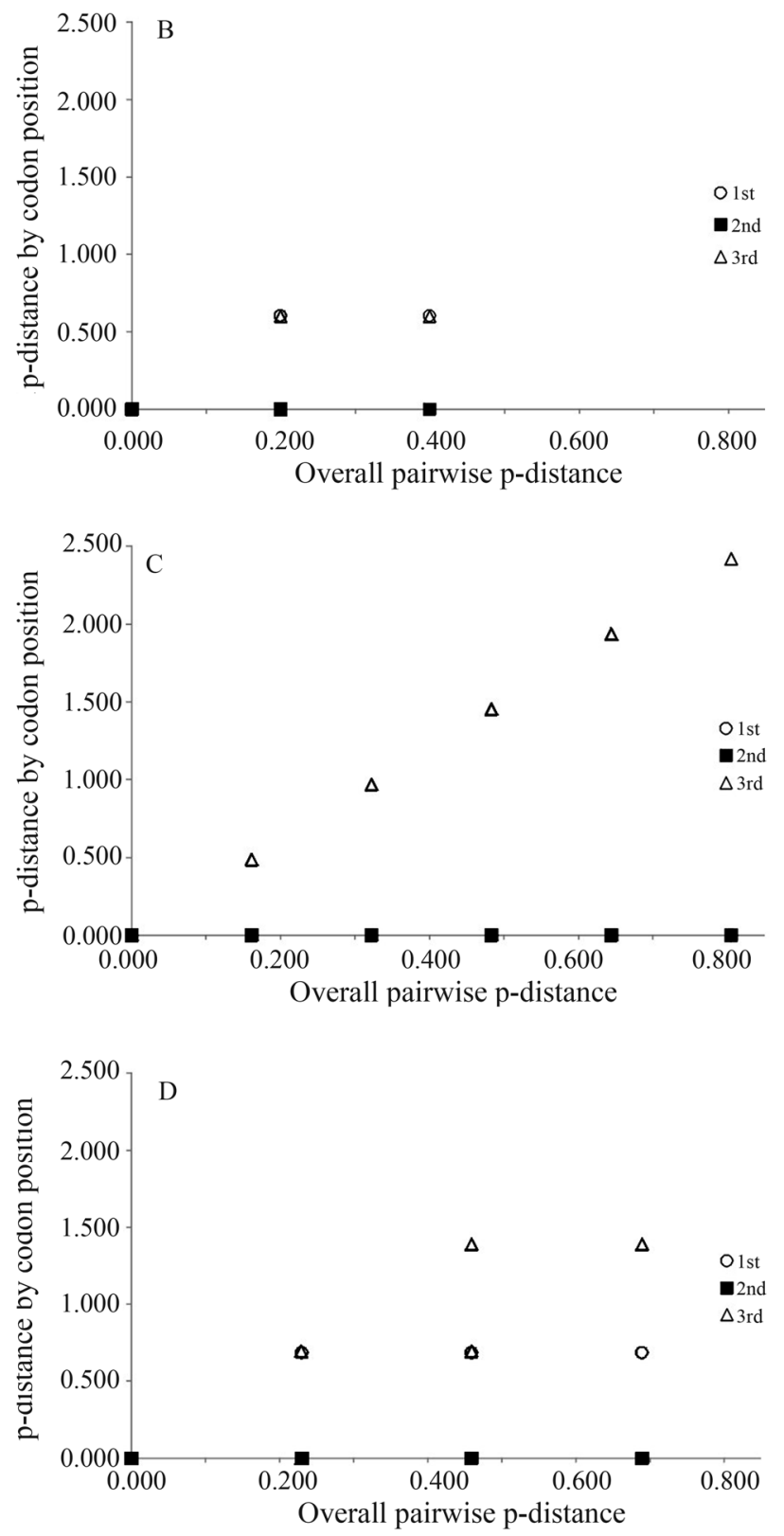

Figure 1 - Percent of overall pairwise divergence, based on a $p$-distance model of nucleotide substitution, plotted as a function of divergence by the codon position of A. cox1 and B. nad6 of Diatraea saccharalis, and C. cox1 and D. nad6 of Hermeuptychia atalanta. 


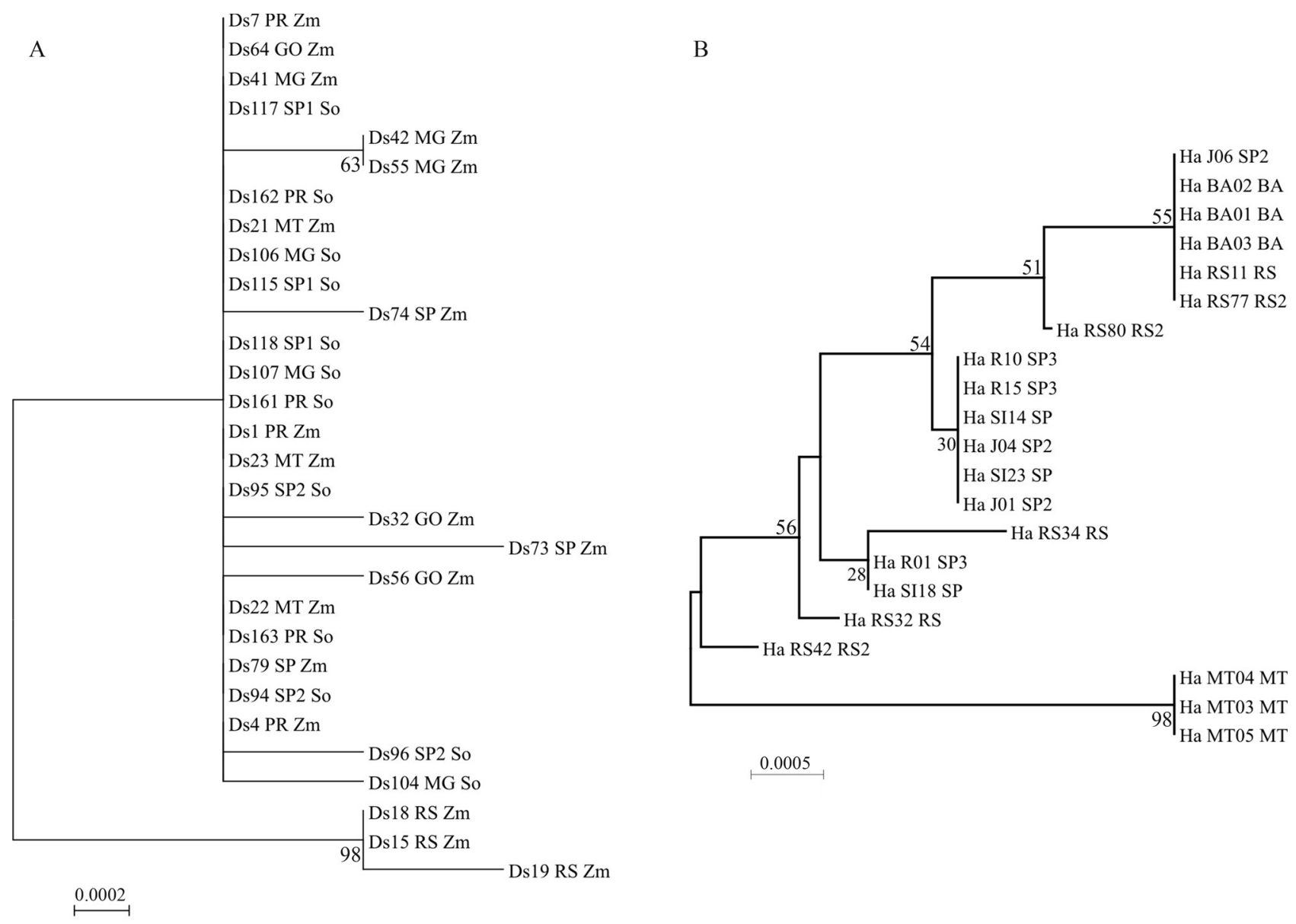

Figure 2 - Neighbor-Joining phenetic relationships among specimens of A. Diatraea saccharalis and B. Hermeuptychia atalanta, based on concatenated data of $\operatorname{cox} 1+$ nad6 sequences and a $p$-distance model of nucleotide substitution. Numbers above the branches are bootstrap values of 1,000 replicates (when values are higher than 50\%). (Ds =D. saccharalis, $\mathrm{SP}=$ São Paulo, $\mathrm{MG}=$ Minas Gerais, $\mathrm{PR}=$ Paraná, $\mathrm{MT}=$ Mato Grosso, $\mathrm{RS}=\mathrm{Rio}$ Grande do Sul; $\mathrm{Zm}=$ corn, $\mathrm{So}=$ sugarcane; $\mathrm{Ha}=$ H. atalanta $; \mathrm{SP}=$ São Paulo, $\mathrm{BA}=$ Bahia, $\mathrm{MT}=$ Mato Grosso, $\mathrm{RS}=$ Rio Grande do Sul).

prising samples from Paranaíta, MT (Ha_MT) (Figure S2). Genetic distances of concatenated data ranged from 0.0 to 0.007. The combined analysis of cox 1 and nad6 resulted in the retrieval of a $\mathrm{NJ}$ tree with improved overall branch resolution (Figure $2 \mathrm{~B}$ ).

Mitochondrial regions are capable of revealing distinct rates of mutation, as well as pronounced heterogeneity at different parts of the molecule (Ballard, 2000; Montooth et al., 2009). In fact, a comparison between genes that codify the subunits of cytochrome oxidase (cox) and nad revealed that, across insect taxa, nad accumulates many more amino acid substitutions than cox, possibly due to a different functional constraint (Montooth et al., 2009). The availability of several mitochondrial genomes of Lepidoptera is now making all these regions accessible for consideration as markers at every taxonomic level. The use of similar and widely tested regions is appealing, since the study of comparable gene regions can contribute synergistically to a broader idea of the evolution of any group of organisms (Caterino et al., 2000). However, for many groups of animals, new regions can be as, or more informative than, the currently used cox1-cox2 sequences (Cameron and Whiting, 2008), specially for exploring variation at the intraspecific level.

Furthermore, nad6 sequences worked as well as cox 1 in recovering DNA variation and genetic relationships among populations of $D$. saccharalis and $H$. atalanta. In this way, nad6 might offer additional information, when complementarily used with other regions in populationgenetics studies, since the combination of multiple genes with variable mutation rates could facilitate the investigation of the complex evolutionary history of a group of organisms (Cameron and Whiting, 2008). The easy amplification of the region presumes the applicability of the proposed designed primers to other Lepidoptera species, manifest through their successful amplification of target DNA of all the species tested, in families as diverse and taxonomically distant as Nymphalidae and Crambidae. Thus, the nad6 region itself can be applied to low level phylogeny and population genetic studies, since the usual inclusion of more than one molecular marker to generate more robust data (Wahlberg and Wheat, 2008), would contribute to- 
wards a more comprehensive view of the evolution of lepidopterans, through facilitating the analysis of comparable gene regions.

\section{Acknowledgments}

This research was supported by the Conselho Nacional de Desenvolvimento Científico e Tecnológico (CNPq) (Projects 480619/2008-5 and 578509/2008-3) and Coordenação de Aperfeiçoamento de Pessoal de Nível Superior CAPES (PRODOC Process 0103/08-0).

\section{References}

Avise JC (1986) Mitochondrial DNA and the evolutionary genetics of higher animals. Phil Trans R Soc Lond Ser B Biol Sci 312:325-342.

Avise JC (2000) Phylogeography: The History and Formation of Species. Harvard University Press, Cambridge, 464 pp.

Ballard JWO (2000) Comparative genomics of mitochondrial DNA in members of the Drosophila melanogaster subgroup. J Mol Evol 51:48-63.

Barros EM, Torres JB, Ruberson JR and Oliveira MD (2010) Development of Spodoptera frugiperda on different hosts and damage to reproductive structures in cotton. Entomol Exp Appl 137:237-245.

Behere GT, Tay WT, Russell DA, Heckel DG, Appleton BR, Kranthi KR and Batterham P (2007) Mitochondrial DNA analysis of field populations of Helicoverpa armigera (Lepidoptera, Noctuidae) and of its relationship to H. zea. BMC Evol Biol 7:e117.

Busato GR, Grutzmacher AD, de Oliveira AC, Vieira EA, Zimmer PD, Kopp MM, Bandeira JD and Magalhães TR (2004) Analysis of the molecular structure and diversity of Spodoptera frugiperda (JE smith) (Lepidoptera, Noctuidae) populations associated to the corn and rice crops in Rio Grande do Sul State, Brazil. Neotrop Entomol 33:709-716.

Cameron SL and Whiting MF (2008) The complete mitochondrial genome of the tobacco hornworm, Manduca sexta, (Insecta, Lepidoptera, Sphingidae), and an examination of mitochondrial gene variability within butterflies and moths. Gene 408:112-123.

Caterino MS, Cho S and Sperling FAH (2000) The current state of insect molecular systematics: A thriving Tower of Babel. Annu Rev Entomol 45:1-54.

Coates BS, Summerford DV and Hellmich RL (2004) Geographic and voltinism differentiation among North American Ostrinia nubialis (European corn borer) mitochondrial cytochrome c oxidase haplotypes. J Insect Sci 4:e35.

Dale VH and Beyeler SC (2001) Challenges in the development and use of ecological indicators. Ecol Ind 1:3-10.

Felsenstein J (1985) Confidence-limits on phylogenies - An approach using the bootstrap. Evolution 39:783-791.

Freitas AVL, Francini RB and Brown KS (2006) Insetos como indicadores ambientais. In: Cullen Jr L, Rudran R and Valladars-Padua C (eds) Métodos de Estudos em Biologia da Conservação \& Manejo da Vida Silvestre. Editora UFPR, Curitiba, pp 125-151.

Gomez PLM, Giraldo C, Lopez A and Uribe S (2009) Molecular and morphological differentiation of Oleria makrena
(Hewitson) and Oleria fumata (Haensch) (Lepidoptera, Ithomiinae). Neotrop Entomol 38:616-623.

Hall TA (1999) BioEdit: A user-friendly biological sequence alignment editor and analysis program for Windows 95/98/NT. Nucleic Acids Symp Ser 41:95-98.

Hebert PDN, Penton EH, Burns JM, Janzen DH and Hallwachs W (2004) Ten species in one: DNA barcoding reveals cryptic species in the neotropical skipper butterfly Astraptes fulgerator. Proc Natl Acad Sci USA 101:14812-14817.

Krafsur ES (2005) Role of population genetics in the sterile insect technique. In: Dyck VA, Hendrichs J and Robinson AS (eds) Sterile insect technique Principles and practice in area-wide integrated pest management. Springer, Dordrecht, pp 389406.

Librado P and Rozas J (2009) DnaSP v5: A software for comprehensive analysis of DNA polymorphism data. Bioinformatics 25:1451-1452.

Martinelli S, Barata RM, Zucchi MI, Silva-Filho MC and Omoto C (2006) Molecular variability of Spodoptera frugiperda (Lepidoptera, Noctuidae) populations associated to maize and cotton crops in Brazil. J Econ Entomol 99:519-526.

Meraner A, Brandstätter A, Thaler R, Aray B, Unterlechner M, Niederstätter H, Parson W, Zelger R, Dalla Via J and Dallinger R (2008) Molecular phylogeny and population structure of the codling moth (Cydia pomonella) in Central Europe: I. Ancient clade splitting revealed by mitochondrial haplotype markers. Mol Phylogenet Evol 4:825-837.

Miller NJ, Dorhout DL, Rice ME and Sappington TW (2009) Mitochondrial DNA variation and range expansion in Western bean cutworm (Lepidoptera, Noctuidae): No evidence for a recent population bottleneck. Environ Entomol 38:274-280.

Molina-Ochoa J, Hutchison WD and Blanco C (2010) Current status of Helicoverpa zea and Heliothis virescens within a changing landscape in the Southern United States and Mexico. Southwest Entomol 35:347-354.

Montooth KL, Abt DN, Hofmann JW and Rand DM (2009) Comparative genomics of Drosophila mtDNA: Novel features of conservation and change across functional domains and lineages. J Mol Evol 69:94-114.

Morinaka S, Maeyma T, Maekawa K, Erniwati Dra, Prijono SN, Ginarsa IK, Nakazawa T and Hidaka T (1999) Molecular phylogeny of birdwing butterflies based on the representatives in most genera of the tribe Troidini (Lepidoptera, Papilionidae). Entomol Sci 2:347-358.

Moritz C, Dowling TE and Brown WM (1987) Evolution of animal mitochondrial DNA - Relevance for population biology and systematics. Annu Rev Ecol Syst 18:269-292.

Nei M and Kumar S (2000) Molecular Evolution and Phylogenetics. Oxford University Press, New York, pp 333.

New TR (1997) Are Lepidoptera an effective ‘umbrella group' for biodiversity conservation? J Insect Conserv 1:5-12.

Saitou N and Nei M (1987) The neighbor-joining method - A new method for reconstructing phylogenetic trees. Mol Biol Evol 4:406-425.

Saw J, Endersby NM and McKechnie SW (2006) Low mtDNA diversity among widespread Australian diamond back moth Plutella xylostella (L.) suggests isolation and a founder effect. Insect Sci 13:365-373.

Silva-Brandão KL, Lyra ML and Freitas AVL (2009) Barcoding Lepidoptera: Current situation and perspectives on the use- 
fulness of a contentious technique. Neotrop Entomol 38:441-451.

Silva-Brandão KL, Wahlberg N, Francini RB, Azeredo-Espin AML, Brown KS, Paluch M, Lees DC and Freitas AVL (2008) Phylogenetic relationships of butterflies of the tribe Acraeini (Lepidoptera, Nymphalidae, Heliconiinae) and the evolution of host plant use. Mol Phylogenet Evol 46:515531.

Simon C, Frati F, Beckenbach A, Crespi B, Liu H and Flook P (1994) Evolution, weighting, and phylogenetic utility of mitochondrial gene sequences and a compilation of conserved polymerase chain reaction primers. Ann Entomol Soc Am 87:651-701.

Tamura K, Peterson D, Peterson N, Stecher G, Nei M and Kumar S (2011) MEGA5: Molecular evolutionary genetics analysis using maximum likelihood, evolutionary distance, and maximum parsimony methods. Mol Biol Evol 28:2731-2739.

Wahlberg N and Wheat W (2008) Genomic outposts serve the phylogenomic pioneers: Designing novel nuclear markers for genomic DNA extractions of Lepidoptera. Syst Biol 57:231-242.

Weller SJ, Pashley DP, Martin JA and Constable JL (1994) Phylogeny of noctuoid moths and the utility of combining independent nuclear and mitochondrial genes. Syst Biol 43:194-211.

Yagi T, Sasaki G and Takebe H (1999) Phylogeny of Japanese papilionid butterflies inferred from nucleotide sequences of the mitochondrial ND5 gene. J Mol Evol 48:42-48.
Yang L, Wei ZJ, Hong GY, Jiang ST and Wen LP (2009) The complete nucleotide sequence of the mitochondrial genome of Phthonandria atrilineata (Lepidoptera, Geometridae). Mol Biol Rep 36:1441-1449.

\section{Internet Resources}

Genetics Home Reference (2011) MT-ND6 - Genetics Home Reference, U.S. National Library of Medicine. http://ghr.nlm.nih.gov/gene/MT-ND6. (July 27, 2011).

\section{Supplementary Material}

The following online material is available for this article:

Figure S1 - Neighbor-Joining phenetic relationships among specimens of $D$. saccharalis based on A. cox 1 and B. nad6 sequences.

Figure S2 - Neighbor-Joining phenetic relationships among specimens of $H$. atalanta based on A. coxl and B. nad6 sequences.

This material is available as part of the online article form http://www.scielo.br/gmb.

Associate Editor: Louis Bernard Klaczko

License information: This is an open-access article distributed under the terms of the Creative Commons Attribution License, which permits unrestricted use, distribution, and reproduction in any medium, provided the original work is properly cited. 

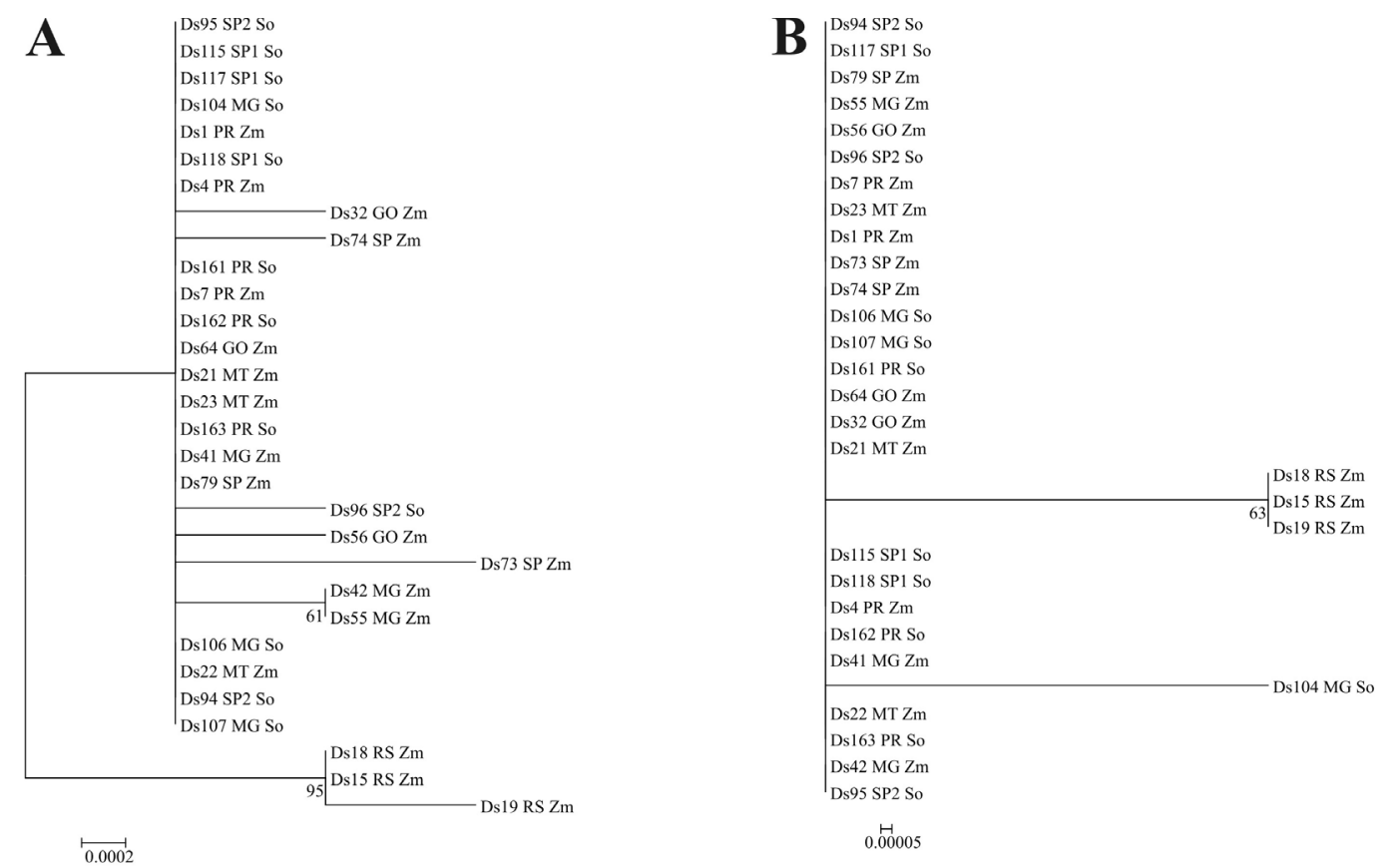

Figure S1 - Neighbor-Joining phenetic relationships among specimens of $D$. saccharalis based on $p$-distance model of nucleotide substitution of A. coxl and B. nad6 sequences. Numbers above branches are bootstraps values of 1,000 replicates (when values are higher than $50 \%$ ).

(Ds = D. saccharalis; $\mathrm{SP}=$ São Paulo, $\mathrm{MG}=$ Minas Gerais, $\mathrm{PR}=$ Paraná, $\mathrm{MT}=$ Mato Grosso, $\mathrm{RS}=$ Rio Grande do Sul; $\mathrm{Zm}=$ corn, $\mathrm{So}=$ sugarcane $)$. 

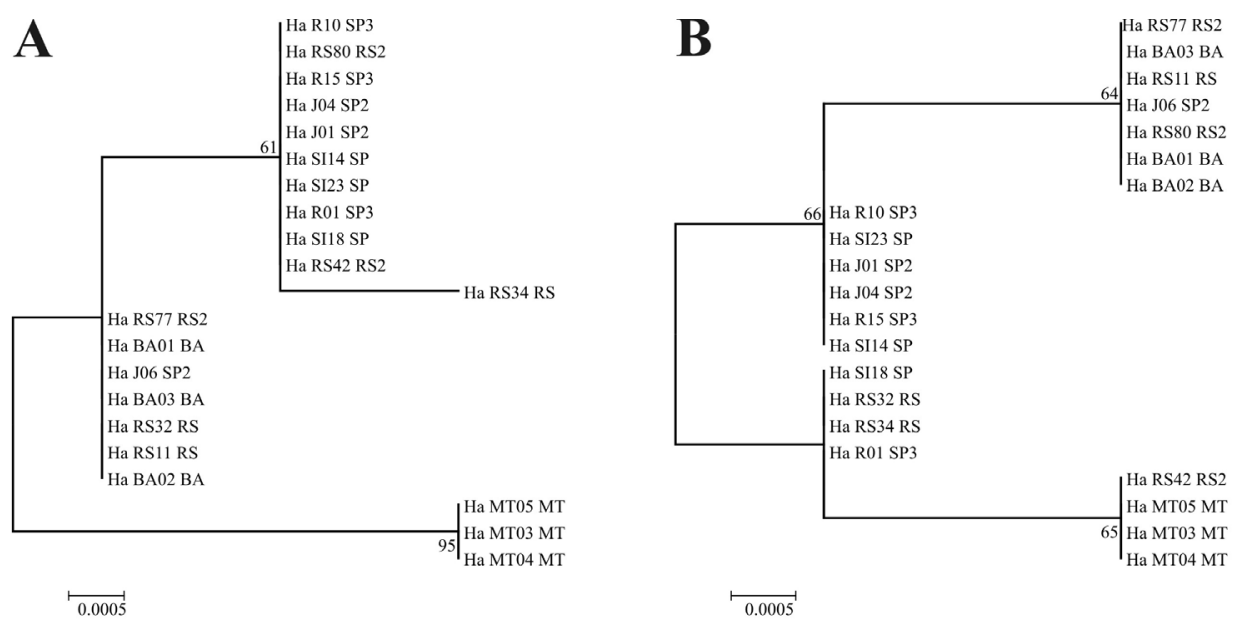

Figure S2 - Neighbor-Joining phenetic relationships among specimens of H. atalanta, based in $p$-distance model of nucleotide substitution. A. cox 1 and B. nad6. Numbers above branches are bootstraps values of 1000 replicates (when values are higher than $50 \%$ ).

$(\mathrm{Ha}=H$. atalanta $; \mathrm{SP}=$ São Paulo, $\mathrm{BA}=$ Bahia, $\mathrm{MT}=$ Mato Grosso, $\mathrm{RS}=$ Rio Grande do Sul $)$. 